\title{
Kemampuan Pemecahan Masalah Mahasiswa pada Materi Mekanika
}

\author{
Ellyna Hafizah, Misbah*, Syubhan Annur \\ Pendidikan IPA FKIP Universitas Lambung Mangkurat, Banjarmasin \\ *Penulis korespondensi, e-mail: ellyna.science.edu@ulm.ac.id
}

\begin{abstract}
Mechanicss is a part of learning in the basic physics course. Mechanics covers kinematics particle and dynamics particle. The materials in mechanics are the topics/discussion which are related to human being life. Considering the characteristics of the materials in the mechanics, the problem solving ability is urgently needed to coprehend the materials. Based on this consideration, students' problem solving ability needs to be analyzed to see the extend of the ability posses by the students to ease the learning. The subjects of the research were the natural science students of Teacher Training and Education Faculty, Universitas Lambung Mangkurat, Banjarmasin. The instrument used were a test which was analyzed using the problem solving ability scoring rubric. The results showed that the students' ability in solving mechanics material in general is good. However, the students commonly missed to check and evaluate the solution so that this step is categorized as less good.
\end{abstract}

Key Words: problem solving; mechanics

\begin{abstract}
Abstrak: Mekanika merupakan bagian dari pembelajaran dalam mata kuliah fisika dasar. Mekanika mencakup kinematika partikel dan dinamika partikel. Pokok bahasan dalam mekanika merupakan suatu bahasan yang sering bersinggungan dengan kehidupan mahasiswa. Melihat karakteristik materi pada mekanika ini maka kemampuan pemecahan masalah sangat diperlukan untuk memahami materi tersebut. Berdasarkan hal tersebut, kemampuan pemecahan masalah mahasiswa perlu untuk dianalisis sejauh mana kemampuan yang sudah dimiliki untuk lebih memudahkan suatu pembelajran. Subjek penelitian ini adalah mahasiswa pendidikan IPA FKIP Universitas Lambung Mangkurat Banjarmasin. Instrumen yang digunakan berupa tes yang kemudian dianalisis menggunakan rubrik penilaian kemampuan pemecahan masalah. Hasil data kemampuan pemecahan masalah berdasarkan penelitian menunjukkan bahwa kemampuan pemecahan masalah mahasiswa termasuk kategori baik. Namun mahasiswa sering melewatkan tahapan uji konsistensi dan koherensi serta mengevaluasi solusi sehingga pada tahap tersebut masih tergolong cukup baik. Adanya beberapa tahap yang masih tergolong cukup baik ini dapat terus ditingkatkan dengan membiasakan suatu proses pembelajaran yang berorientasi pada masalah terutama masalah nyata.
\end{abstract}

Kata kunci: pemecahan masalah; mekanika

\section{Pendahuluan}

Capaian Pembelajaran Lulusan (CPL) pada mata kuliah fisika dasar adalah menganalisis konsep fisika dasar berdasarkan deduksi fakta-fakta dan data pengamatan laboratorium. Berdasarkan CPL yang harus dicapai, maka agar mahasiswa mampu menganalisis diperlukan penguaasan konsep pada mata kuliah fisika dasar. Selain penguasaan konsep menerapkan konsep atau prinsip dalam persoalan fisika juga merupakan komponen yang tidak terpisahkan, maka dari itu perlu dilatihkan suatu keterampilan procedural, dalam hal ini kemampuan mahsiswa dalam memecahkan masalah fisika. Kemampuan pemecahan masalah sangat perlu

How to Cite:

Hafizah, E., Misbah, M., \& Annur, S. (2018). Kemampuan pemecahan masalah mahasiswa pada materi mekanika. Momentum: Physics Education Journal, 2(2). https://doi.org/10.21067/mpej.v2i2.2729

This is an open access article under the CC BY license (http://creativecommons.org/licenses/by-nc-nd/4.0/) https://doi.org/10.21067/mpej.v2i2.2729 
kepada mahasiswa, karena kehidupan di masa mendatang menuntut pemecahan masalah kehidupan dengan cara yang inovatif (Dwi, dkk, 2013).

Materi mekanika sebagai salah satu bagian materi dalam mata kuliah fisika dasar mempunyai karakteristik materi yang unik dalam pembelajaran. Mekanika merupakan cabang ilmu fisika yang mempelajari kinematika dan dinamika partikel. Kinematika partikel mempelajari tentang gerak partikel tanpa memperhatikan penyebab geraknya. Sedangkan dinamika partikel mempelajari penyebab dari gerak suatu partikel. Materi mekanika sangat mudah dinyatakan, namun sering mendapat kesulitan dalam memahami (Zemansky dan Sears, 2002).

Materi mekanika termasuk salah satu materi yang memerlukan pemecahan masalah. Dalam proses pemecahan masalah tersebut harus didampingi dengan bantuan media lain untuk memperjelas konsep, seperti pada pembahasan gaya gesek. Mahasiswa perlu mengetahui bahwa permukaan benda memiliki tingkat kekasaran. Pada skala mikroskopik, gaya gesek dan gaya normal merupakan hasil dari gaya-gaya intermolekuler antar dua pemukaan (Zemansky dan Sears, 2002). Tingkat kekasaran permukaan yang sangat kecil hanya dapat dilihat mengunakan media lain. Selain itu, mahasiswa perlu diajarkan cara mengambar vektor yang benar untuk mempelajari materi mekanika partikel. Hal ini menghindari terjadinya miskonsepsi pada mahasiswa. Beberapa mahasiswa mengalami miskonsepsi pada hukum satu Newton, seperti menganggap kecepatan konstan karena ada gaya yang mendorong (Itza-Ortiz, dkk, 2004). Mahasiswa sering mengalami miskonsepsi pada hukum dua Newton dibandingkan hukum satu Newton dan hukum tiga Newton (Aslan \& Devecioglu, 2010). Mahasiswa kurang paham konsep hukum Newton walaupun memahami hukum Newton secara matematika (Ouattara \& Oué draogo, 2012).

Berdasarkan karakteristik materi mekanika partikel tersebut, maka kemampuan pemecahan masalah mahasiswa merupakan bagian penting untuk diketahui. Masalah adalah ketidaksesuaian antara tujuan atau harapan dengan kenyataan. Masalah ada hanya ketika mahasiswa dihadapkan dengan kesulitan menentukan jawaban yang tepat dengan cepat. Tidak semua pertanyaan adalah masalah, tapi hanya pertanyaan yang menimbulkan konflik dalam pikiran mahasiswa. Hal ini sejalan dengan pendapat Adair (2007) bahwa kemampuan pemecahan masalah merupakan bagian dari suatu keputusan yang sudah dibuat sehingga diperlukan suatu kemampuan untuk menyelesaikannya.

Kemampuan pemecahan masalah menurut Santrock (2011) merupakan hasil dari pemikiran yang dilakukan dengan efektif serta melalui proses atau langkah pemecahan. Sedangkan menurut Gok dan Silay (2008), kemampuan pemecahan masalah adalah kemampuan siswa menggunakan informasi yang ada untuk menentukan apa yang harus dikerjakan dalam suatu keadaan tertentu.

Kemampuan pemecahan masalah merupakan salah satu bagian dari keterampilan berpikir tingkat tinggi yang perlu dilatihkan di Perguruan Tinggi. Kemampuan pemecahan masalah merupakan suatu kemampuan yang dapat dilatihkan kepada para mahasiswa. Pemecahan masalah dapat dilakukan dengan empat tahap pemecahan masalah yang telah dikembangkan Polya. Namun strategi Polya ini dirasa sulit bagi para pemula sehingga dikembangkan menjadi enam tahap pemecahan masalah (Rojas, 2010). Kemampuan pemecahan masalah dalam penelitian ini diukur berdasarkan jawaban mahasiswa berdasarkan enam tahap kemampuan pemecahan masalah pada Tabel 1 berikut.

Tabel 1 Tahap Kemampuan Pemecahan Masalah

\begin{tabular}{lll}
\hline \multicolumn{1}{c}{ Tahap } & \multicolumn{1}{c}{ Kegiatan Mahasiswa } \\
\hline 1 Menjelaskan masalah & Memahami kondisi masalah dengan \\
& mengetahui masalah, hal-hal yang \\
& diketahui dan ditanyakan \\
& Merumuskan masalah dengan \\
& menggunakan konsep-konsep fisika \\
& serta mencatat informasi yang \\
& diberikan untuk memecahkan masalah \\
\hline
\end{tabular}


2 Mendiskripsikan masalah secara kualitatif

$3 \quad$ Merencanakan solusi

4 Menjalankan rencana

5 Menguji konsistensi dan koherensi persamaan yang digunakan

6 Mengecek dan mengevaluasi solusi

\section{Kegiatan Mahasiswa}

- Memahami arti kualitatif dari persamaan yang berkaitan dengan masalah

- Berpikir dan menuliskan hukum, prinsip , atau formulasi kemungkinan yang bisa membantu siswa untuk memecahkan masalah

- Memilih salah satu strategi solusi dan menuliskan formulasi matematis yang sesuai dengan masalah

- Memilih informasi-informasi lain yang mendukung untuk pemecahan masalah

- Mencoba menemukan solusi dengan menggunakan informasi yang sudah diketahui serta menjalankan strategi pemecahan masalah sebelumnya

- Menyelesaikan dua kasus berbeda dengan persamaan yang sama. Siswa dapat membuat penyesuaian persamaan untuk tiap kasus.

- Mengevaluasi solusi yang didapatkan apakah solusi tersebut dapat memecahkan masalah yang diajukan atau dapatkan solusi tersebut menyelesaikan masalah yang lebih umum.

Sumber: adaptasi dari Rojas, (2010)

Berdasarkan permasalahan yang ada serta karakteristik materi mekanika itu sendiri, maka perlu dianalisis sejauh mana tingkat kemampuan pemecahan masalah fisika. Agar jika rendah tingkat kemampuan pemecahan masalahnya maka bisa diperbaiki atau ditingkatkan. Jika sudah baik maka perlu dipertahankan dengan strategi perkuliahan tertentu.

\section{Metode}

Metode penelitian yang digunakan pada penelitian ini menggunakan metode penelitian deskriptif kuantitatif. Subjek penelitian ini adalah mahasiswa pendidikan IPA FKIP ULM yang mengambil mata kuliah fisika dasar. Kemampuan pemecahan masalah mahasiswa didapatakan dari hasil tes kemampuan pemecahan masalah menggunakan tes essai kemampuan pemecahan masalah sebanyak 5 buah.

Hasil tes kemampuan pemecahan masalah dianalisis berdasarkan rubrik pemecahan masalah yang mengaju pada tahapan kemampuan pemecahan masalah pada Tabel 1. Setiap tahap kemampuan pemecahan masalah mahasiswa mempunyai skor maksimum 4 dan minum 1 . Jadi dalam satu soal skor maksimum yang dapat diperoleh mahasiswa adalah 24 .

Jumlah skor yang didapatkan mahasiswa pada 5 buah soal kemampuan pemecahan masalah tersebut dibandingkan dengan skor maksimum kemampuan pemecahan masalah yang mungkin didapatkan. Hasil ini kemudian dinyatakan dalam suatu persentase agar bisa dideskripsikan sesuai Tabel 2 berikut.

Tabel 2 Deskripsi Persentase Kemampuan Pemecahan Masalah

\begin{tabular}{cll}
\hline No & Persentase & Kategori \\
\hline 1 & $76-100 \%$ & Sangat baik \\
2 & $51-75 \%$ & Baik \\
3 & $26-50 \%$ & Cukup baik \\
\hline
\end{tabular}


$4 \quad 0-25 \% \quad$ Kurang baik

\section{Hasil dan Pembahasan}

Data yang diperoleh pada penelitian ini merupakan data kuantitatif hasil tes kemampuan pemecahan masalah mahasiswa. Data nilai kemampuan pemecahan masalah mahasiswa yang diperoleh tiap tahap pemecahan masalah sesuai pada Tabel 1 dibandingkan dengan nilai maksimum yang mungkin didapat pada tiap tahap tersebut. Hasil perbandingan ini selanjutnya dinyatakan dalam suatu persentase agar dapat dideskripsikan sesuai dengan kriteria yang terdapat pada Tabel 2.

Secara lengkap data hasil kemampuan pemecahan masalah mahasiswa pendidikan IPA sesuai dengan tahapan pemecahan masalah yang dikembangkan (Rojas, 2010) dan dinyatakan pada Tabel 3 berikut ini.

Tabel 3 Data Kemampuan Pemecahan Masalah Fisika Mahasiswa Pendidikan IPA

\begin{tabular}{|c|c|c|}
\hline Tahap & Kegiatan Mahasiswa & Persentase \\
\hline Menjelaskan masalah & $\begin{array}{l}\text { - Memahami kondisi masalah dengan mengetahui } \\
\text { masalah, hal-hal yang diketahui dan ditanyakan } \\
\text { - Merumuskan masalah dengan menggunakan } \\
\text { konsep-konsep fisika serta mencatat informasi } \\
\text { yang diberikan untuk memecahkan masalah }\end{array}$ & $65,31 \%$ \\
\hline $\begin{array}{l}\text { Mendiskripsikan masalah secara } \\
\text { kualitatif }\end{array}$ & $\begin{array}{l}\text { - Memahami arti kualitatif dari persamaan yang } \\
\text { berkaitan dengan masalah } \\
\text { - Berpikir dan menuliskan } \\
\text { hukum, prinsip, atau formulasi kemungkinan } \\
\text { yang bisa membantu siswa untuk memecahkan } \\
\text { masalah }\end{array}$ & $60,28 \%$ \\
\hline Merencanakan solusi & $\begin{array}{l}\text { - Memilih salah satu strategi solusi dan menuliskan } \\
\text { - } \text { Mermulasi matematis yang sesuai dengan masalah } \\
\text { untuk pemecahan masalah }\end{array}$ & $59,25 \%$ \\
\hline Menjalankan rencana & $\begin{array}{l}\text { - Mencoba menemukan solusi dengan } \\
\text { menggunakan informasi yang sudah diketahui } \\
\text { serta menjalankan strategi pemecahan masalah } \\
\text { sebelumnya }\end{array}$ & $65,50 \%$ \\
\hline $\begin{array}{l}\text { Menguji konsistensi dan } \\
\text { koherensi persamaan yang } \\
\text { digunakan }\end{array}$ & $\begin{array}{l}\text { - Menyelesaikan dua kasus berbeda dengan } \\
\text { persamaan yang sama. Siswa dapat membuat } \\
\text { penyesuaian persamaan untuk tiap kasus }\end{array}$ & $45,67 \%$ \\
\hline $\begin{array}{l}\text { Mengecek dan mengevaluasi } \\
\text { solusi }\end{array}$ & $\begin{array}{l}\text { Mengevaluasi solusi yang didapatkan apakah } \\
\text { solusi tersebut dapat memecahkan masalah yang } \\
\text { diajukan atau dapatkah solusi tersebut } \\
\text { menyelesaikan masalah yang lebih umum. }\end{array}$ & $40,00 \%$ \\
\hline
\end{tabular}

Berdasarkan Tabel 3 diatas pada tahap menjelaskan masalah didapatkan persentase sebesar $65,31 \%$ yang dapat dikategorikan baik. Pada tahap ini mahasiswa menuliskan komponen apa saja yang dapat diketahui dari permasalahan yang disajikan. Namun hanya sebagian yang mampu menjelaskan masalah melalui konsep-konsep fisika yang terkait. Beberapa diantaranya mengalami kesulitan dalam menjelaskan masalah melalui konsep fisika yang terkait.

Pada tahap mendiskripsikan masalah secara kualitatif didapatkan hanya 60,28\% yang mampu melakukan tahap ini, berdasarkan persentase tersebut tahap ini termasuk dalam kategori baik. Tahap ini 
kebanyakan mahasiswa masih mengalami kesulitan dalam menentukan formulasi kemungkinan yang mungkin dapat digunakan.

Tahap merencanakan solusi dan menjalankan rencana didapatkan persentase sebesar $59,25 \%$ dan $65,50 \%$, yang dapat dikategorikan baik. Kedua tahap ini dalam proses analisis menggunakan rubrik penilaian, data yang didapatkan merupakan satu kesatuan yang unik. Didapatkan ada kecenderungan dalam jawaban mahasiswa bahwa ketika telah memilih kemungkinan formulasi yang digunakan, selanjutnya pada tahap menjalankan rencana dengan menggunakan persamaan matematis didapatkan mahasiswa mampu menjalankan dengan baik. Artinya pada kedua tahap ini mahasiswa lebih mengalami kesulitan dalam merencakan solusi yang tepat yang sesuai dengan masalah dibandingkan dengan menggunakan kemampuan matematisnya.

Tahap menguji konsistensi dan koherensi persamaan yang digunakan serta mengevaluasi solusi didapatkan persentase $45,67 \%$ dan $40,00 \%$ yang dapat dikategorikan cukup baik. Hal ini menunjukkan mahasiswa kebanyakan tidak mampu menyelesaikan kasus yang berbeda dengan persamaan yang sama. Ketika dihadapkan pada permasalahan yang sama namun dengan konteks yang berbeda mahasiswa mengalami kesulitan. Tahap mengevaluasi ini kebanyakan mahasiswa melewatkan hal tersebut.

Berdasarkan data di atas didapatkan bahwa kemampuan pemecahan masalah mahasiswa pendidikan IPA pada materi mekanika tergolong baik. Kemampuan pemecahan masalah pada dasarnya merupakan hakekat tujuan pembelajaran yang menjadi kebutuhan siswa dalam menghadapi kehidupan nyata (Taufik, dkk, 2010). Kemampuan pemecahan merupakan bagian dari kemampuan berpikir tingkat tinggi mahasiswa yang dapat dilatihkan. Kemampuan pemecahan masalah seseorang dapat dilihat dari cara memahami masalah, merencanakan pemecahan masalah, melaksanakan pemecahan masalah, dan menafsirkan hasil dari masalah tersebut.

Namun pada dua tahap terakhir pada tahap kemampuan pemecahan masalah, kemampuan pemecahan masalah mahasiswa pendidikan IPA masih dalam kategori cukup baik. Adanya beberapa tahap kemampuan pemecahan masalah yang cukup baik ini dapat terus ditingkatkan. Salah satu cara yang dapat ditempuh dalam pembelajaran agar mutu pembelajaran dan kemampuan berpikir dapat ditingkatkan adalah dengan mengintensifkan pengembangan kemampuan mahasiswa (Sambada, 2012). Selain itu kemampuan pemecahan masalah dapat ditingkatkan dengan cara mengidentifikasi setiap kesulitan dalam tahapan pemecahan masalah yang dialami mahasiswa (Meera, 2012). Identifikasi kesulitan pemecahan masalah ini diharapakan mampu memberikan gambaran kepada pengajar untuk dapat memberikan bantuan secara lebih intensif serta pola-pola baru untuk dapat terus mengintensifkan kemampuan pemecahan masalah mahasiswa.

Cara yang dapat dilakukan untuk mengintensifkan pengembangan kemampuan mahasiswa adalah dengan menggunakan metode atau model pembelajaran yang mengorientasikan mahasiswa pada masalah nyata. Pembelajaran yang mengorientasikan pada masalah nyata dapat menciptakan keterlibatan mahasiswa dalam proses belajar mengajar untuk menumbuhkan kemampuan memecahkan masalah. Hal ini sejalan dengan penelitian Manalu, 2016 yang menyatakan bahwa keterlibatan siswa secara aktif merupakan upaya pengembangan untuk menjadikan pembelajar yang mandiri dan meningkatkan kemampuan berfikir siswa. Selain itu Sihotang, 2016 menyatakan bahwa model pembelajaran berbasis masalah mampu menjadikan mahasiswa terampil menganalisis dan menyelesaikan suatu masalah yang dihadapkan pada siswa, menjadikan siswa belajar secara langsung dengan pemberian pengalaman secara langsung yang berkaitan dengan kehidupan sehari-hari sehingga siswa menemukan dan mampu memecahkan masalah. Penggunaan model maupun metode yang berorientasi pada masalah serta aktivitas siswa membuat siswa lebih mampu untuk mengutarakan ide maupun gagasan (Gregorcic, 2017). 


\section{Simpulan}

Kemampuan pemecahan masalah mahasiswa pendidikan IPA pada materi mekanika secara umum termasuk dalam kategori baik. Namun pada tahap uji konsistensi dan koherensi yang digunakan pada permasalahan yang berbeda berada pada kategori cukup baik. Selain itu tahap evaluasi solusi juga masih berada pada kategori kurang baik. Adanya beberapa tahap yang masih tergolong cukup baik ini dapat terus ditingkatkan dengan membiasakan suatu proses pembelajaran yang berorientasi pada masalah terutama masalah nyata.

\section{Daftar Rujukan}

Adair, J. (2007). Decision Making \& Problem Solving Strategies. London: Kogan Page.

Aslan, A. S \& Devecioglu. (2010). Student teachers' levels of understanding and model of understanding abaout Newton's laws of motion. Journal Asia-Pasicific Forum on Science Learning and Teaching. 11 (1), 7-10.

Dwi, I. M., Arif, H. \& Sentot, K. (2013). Pengaruh Strategi Problem Based Learning Berbasis ICT terhadap Pemahaman Konsep dan Kemampuan Pemecahan Masalah Fisika. Jurnal Pendidikan Fisika Indonesia, 9: 8-17. Retrieved from http://journal.unnes.ac.id/nju/index.php/jpfi.

Gok, Tolga \& Ilhan Silay. (2008). Effects Of Problem-Solving Strategies Teaching On The Problemsolving Attitudes Of Cooperative Learning Groups In Physics Education. Journal of Theory and Practice in Education, 4 (2): 253-266. Retrieved from http://eku.comu.edu.tr/index /4/2/tgok_isilay.pdf.

Gregorcic, B., Planinsic, G. \& Etkina, E. (2017). Doing science by waving hands: Talk, symbiotic gesture, and interaction with digital content as resources in student inquiry. Physical Review Physics Education Research, 13(2).

Itza-Ortiz, S. F, Rebello, S \& Zoliman, D. (2004). Student's Model of Newton's Second Law in Mechanics and Electromagnetism. European Journal of Physics, 25 (2): 152-159.

Manalu, A. (2016). Efek Model Problem Based Learning Terhadap Kemampuan Pemecahan Masalah Siswasma Negeri 2 Pematangsiantar. INPAFI (Inovasi Pembelajaran Fisika), 4(2):100-105.

Meera, B. N. (2012). How do they solve it? An insight into the learner's approach to the mechanism of physics problem solving. Physical Review Special Topics - Physics Education Research, 8(1).

Ouattara, F \& Oudraogo, O. (2012). Investigasi on Teaching and Learning Mechanics in the Terminal Scientist Classes of Burkina Faso Secondary School. International Journal of Physical and Social Sciences, 2(9): 235-241.

Rojas, S. (2010). On the Teaching and Learning of Physics Problem Solving. Revista Mexicana De Fi'Sica, 56 (1): 22-28. Retrieved from http://www.scielo.org.mx/ pdf/rmfe/v56n1/v56n1a4.pdf.

Sambada, D. (2012). Peranan Kreativitas Siswa Terhadap Kemampuan Memecahkan Masalah Fisika dalam Pembelajaran Kontekstual. Jurnal Penelitian Fisika dan Aplikasinya (JPFA), 2(2).

Santrock, J. W. (2011). Educational Psychology. Library of Congress Cataloging-in-Publication Data.

Sihotang, A., \& Simatupang, S. (2016). Pengaruh Model Pembelajaranberbasis Masalahmenggunakananimasiterhadapkemampuanpemecahan Masalah Fisika Siswakelas X SMA N1 Sumbul. INPAFI (Inovasi Pembelajaran Fisika), 4(4). 
Taufik, M., Sukmadinata, S., Abdulhak, I., \& Tumbelaka, B. Y. (2010). Desain Model Pembelajaran Untuk Meningkatkan Kemampuan Pemecahan Masalah Dalam Pembelajaran IPA (Fisika) Sekolah Menengah Pertama di Kota Bandung. Berkala Fisika, 13(2), 31-44.

Zemansky \& Sear. (2002). Fisika Universitas. Jakarta: Erlangga. 